\title{
Second Life: A Hope for Ideal, But Only in Its Imaginary
}

\author{
Xiaowei Huang ${ }^{1}$ \\ ${ }^{1}$ Division of Culture and Creativity, BNU-HKBU United International College, Zhuhai, China \\ Correspondence: Xiaowei Huang, Division of Culture and Creativity, BNU-HKBU United International College, \\ Zhuhai, Guangdong Province, 519000, China. Tel: 86-188-0253-8544. E-mail: janey710@126.com
}

Received: January 14, 2021

doi:10.5539/ass.v17n2p109
Accepted: January 22, $2021 \quad$ Online Published: January 31, 2021

URL: https://doi.org/10.5539/ass.v17n2p109

\begin{abstract}
Second Life, one of the most popular of virtual world was invented by Linden Lab Corporation: its philosophical statement is that Second Life is 'a place where you can turn the pictures in your head into a kind of pixelated reality' (Rymaszewski, 2007, p. iv). Second Life is, for many reasons to be considered in this essay, a representative example of the (offline/real) world. This paper will argue that virtual worlds such as Second Life are an extension of the real world. Two major questions were posed earlier in this essay: 'Does the virtual world represent the real world?' and 'Is it a refuge for its participants from the real world'. We can answer these questions. First of all, the virtual world is an extension of the real world, because it is built from, and continues to make use of, ideas, meanings, identity categories, performances, narratives and values derived from the real world. Secondly, Second Life is clearly not, in the long term, a refuge for its participants from the real world. Second Life can be understood as a virtual place that allows people to have temporary fun; however, it is only for a moment or for a short period, because the relationship between the virtual and the real world is interpenetrated.
\end{abstract}

Keywords: virtual world, Second Life, virtual culture, discourse, spectacle

\section{Introduction}

\subsection{A Virtual Community - Second Life}

Second Life is invented by the Linden Lab from San Francisco, the US. As to many people who have never registered as a member of it, Second Life is assumed as a sort of online games. For some people, they also wonder if Second Life is an online date site. It is not hard to understand why people's assumptions about Second Life are not accurate. Second Life shares some similarities with other online entertainments, such as role-play games, which also reqests to be accessed by the connection of Internet. Moreover, online games also provide conversation tools for users to chat and communicate with each other. However, the main notion of Second Life is to pick up a new identity and chat with other residents. There are several games offered from different destinations, but most residents join Second Life is for chatting and joining activities purposes instead of playing games.

The notion that virtual communities such as Second Life can function as real communities, in the way that characterizes a village, town, state or even a nation, is taken up and explored by Boellstorff (2008). In his book, which is a kind of 'virtual ethnography', he argues that, although online sites such as Second Life differentiate themselves from the real world and seem to offer something more or better than ordinary, real world life, the 'virtual worlds reference and respond to the actual worlds in many ways' (2008, p. 4).

Boellstorff makes the point that virtual worlds play a key role in influencing social life (2008, p. 5). He suggests that 'in virtual worlds we are not quite human - our humanity is thrown off balance, considered anew, and reconfigured through transformed possibilities for place-making, subjectivity, and community' (2008, p. 5).

\subsection{Virtual Culture and Discourse}

Second Life is a particularly useful case study for researching virtual worlds, because it has a particularly well developed culture and a discourse on and about that culture and activities, values, imperatives and logics. While there is a single 'official' culture to Second Life, there are also subcultures. If we go into the site we can find people participating in a church service, virtual newspapers being sold on a newsstand, and virtual courses being offered by a virtual university (2008, p. 8).

There are no temporal or geographical limitations: people can visit your friends in San Francisco in the early 
morning, then dinner with your mum in Beijing. Your virtual life experience can begin with saying hello by typing words onto the screen and waiting for answers. You may get response from a numbers of people within a minute. You can go shopping for new clothes for your avatar or a costume party. In this way, our real world, physical identities are transported and integrated into the virtual world.

\section{Virtual Achievements and Satisfaction}

People go into and use Second Life for a variety of purposes. People who are dissatisfied or unhappy in the actual world because of problems regarding their family, career and sexuality, may access Second Life to give themselves a second chance, a second life, and for some users, moving to Second Life constitutes a sort of escaping from the realities of everyday life.

It can be argued that virtuality has always characterized human culture (Boellstorff, 2008, p.33). McLuhan points out, for instance that 'the development of writing can also be seen as the technology making virtual worlds possible' (1962). Ong connects the idea of writing with Plato's argument that writing is a thing, a product that has been modified in mind; it is a piece of artificial modification. Boellstorff suggests that the invention of role-playing game and the development of video games are ancestors of virtual worlds (cited in Rheingold, 2000, p. xv; Sterling, 1992, p. 108). Bartle also argues that 'virtual worlds originate above all from video games' (2004:4). On-line games, especially role-playing games, provide opportunities for the players to take on and perform various identities.

\subsection{Virtual World vs. Actual World}

Since the virtual world is a new concept, it is to be expected that people bring actual life meanings and ideas to virtual worlds. However people's sociality in virtual worlds is not the same as in the actual-world. Moreover, scholars have considered and discussed whether or not virtual worlds can be considered as places. According to Rutter and Smith, "place" and "virtual" cannot coexist: "there is not 'place' in the virtual beyond the metaphor" (cited in 2005, p. 85).

People who participate in virtual worlds such as Second Life are now offered 3D environments that simulate the actual world. It brings so much actual experience to the users as what they use to gain from the real world. This 'simulation of the actual constitutes the basis of social relations. As Cosgrove points out:

In the dominant Western tradition, vision and place are linked through the idea of the landscape, which "represents a way of seeing - a way in which some Europeans have represented to themselves and to others the world about them and their relationship with it, and through which they have commented on social relations (1998, p. 1).

For Healy virtual worlds such as Second Life are places, because even a simulated place is made meaningful as a place by an observer who sees by and through socio-cultural frames (and limitations. A 3D environment provides users with a real world experience: as it is a simulation of the real world, the meanings given to a place through seeing and observing effectively 'make that place'.

\subsection{Virtual Identity}

It is important to analyze issues and differences of identity across virtual and actual world. What is at issue is the extent to which actual and online identity is continuous. In Second Life people can behave and act differently to what they might do in the actual world. Participants in virtual worlds used to be called "users", "gamers," or "players", and these terms are still used quite often in the study of Second Life: however, other terms have been added, such as residents and members.

In order to survive in the actual world, people have to play multiple roles, and assume different identities. We are a different type of identity with out family (a daughter, a sister, a mother) from the identity we have in social and work contexts. Everyone has to change their performance once their role-as-identity changes. Different nationalities are often expected to perform in keeping with national stereotypes.

Fornas et al. write about "how identities "are not produced by sovereign and autonomous subjects alone ... identity-producing interactions take place in the use of communicative and signifying practice"' (cited in Fornas et al., 2002, p. 34). For Foucault, "such "identity-producing interactions" are "technologies of the self" (cited in Foucault 1986). The gap between virtual and actual world identities (and performances) has caught the attention of researchers.

One of the most significant differences between Second Life and other virtual worlds is the avatar. As Taylor and Hudson-Smith explain, avatars are not just abstract anchors of virtual perspective; they were the modality through which residents experienced virtual selfhood, and "central to both immersion and the construction of 
community in virtual space (cited in Taylor, 2006a, p. 110; see also Hudson-Smith, 2002, p. 82).

The avatar is the screen name and representation that stands in for you to the other. Some residents confirm that the avatar does play an important role in their interaction with other residents in Second Life. The style, content and decorative aspects of an avatar is a personal decision. Some people choose an avatar that reflects their physicality.

The question of the relationship between actual identity categories based on factors such as gender and race, and online or virtual identity has been an important topic of research in this field. Second Life provides its residents with the freedom to select their gender. The first step for Second Life residents is to set up a gendered avatar: but this not need be consistent with their actual gender. People who are dissatisfied with their gender (or the limitations that are placed on their desires because of their gender identity) in actual life use the virtual world as an escape and as a chance to change their identity, even if only temporarily. Gender has been a topic of interest in virtual worlds and has attracted much scholarly attentions.

\section{Communities and Friendships}

Besides offering so much confident to its residents, Second Life also plays a key role in building up social communities, networks and friendships. One of the key aspects of social life on Second Life is sexual activity and finding sexual partners. For Mills, sex is main reason why people visit and frequent virtual worlds: regardless of claims about the breadth of other social activities in virtual worlds, sex is still the primary goal of virtual activities. Mills suggests 'the ostensibly generic term "cybering" had become a synonym for sex, rather than for chatting, building a structure, or any other activity’ (cited in Mills, 1998).

It is interesting to note that at a public level, avatars cannot include certain parts of the human body, such as genitalia. However businesses do cater, at a private level, for 'sexual services' that include genitalia, bondage devices and 'sexualized' landscapes All these products produce an environment/place for virtual sex activity. Sexual activities include both private relationships and group sex, as well as sexual work such as 'prostitution or sexualized environments such as strip clubs' (Boellstorff, 2008, p. 161).

\section{Society of the Spectacle}

The spectacle, like Second Life, replaces the actual world with a series of dramatic, unusual, fascinating fantasies and performances: think of the way in which, in Second Life, the actual person is replaced by something more beautiful, interesting, glamorous, colorful, attractive and unusual, to the extent that the actual person (in fact, any actual person) cannot compete with this kind of 'spectacular identity'. As Debord writes: the spectacle 'manifests itself as ... out of reach ... All it says is: "Everything that appears is good; whatever is good will appear'" (Debord, 1983, p. 15). To some extent, the spectacle, is everywhere no matter in the real world or the virtual world. This is clearly show through Second Life's residents in the way how they behave, how they act, in particular, what kind of avatar they select as the representation of themselves.

In the real world/offline world, people have to adjust their behavior, keep an eye on their perforformance in order to be appropriate for a particular event or a specific culture. The reason why people have to pay so much attention on their own is manily due to the surveillance by others, as well as by themselves. In general, we cannot say, everybody do the same things, which means that every member in the society is so caution on how they present themselves to other is an issue, however, we would say that the majority of people do concern about if they belong to a culture, or if we can use the word that they look 'normal' to others. In the virtual world, such as Second Life, even though it claims that it offers unlimited freedowm to the residents, we may raise up the question of "how many of us can truly enjoy the freedom in Second Life?" The one who are in control of the avatar as well as the keyboard, it is hard to answer this question simply because of the virtual world's residents are also the residents in the real world. Our physical appreance can be different but our mind remains the same wherever we are.

\section{Conclusion}

It is clear, from the evidence presented, that virtual worlds such as Second Life are an extension of the real world. Some residents claim that Second Life provides endless freedom to its users, and people there can be themselves. In the real world, people more or less have to care how others see their body, image, and clothes:, this is reflected in Second Life.

Secondly, Second Life is clearly not, in the long term, a refuge for its participants from the real world. Second Life can be understood as a virtual place that allows people to have temporary fun; however, it is only for a moment or for a short period, because the relationship between the virtual and the real world is interpenetrated. 


\section{References}

Au, J. (2003). Tax Revolt in Americana! New World Notes (September 12). Retrieved from http://nwn.blogs.com/nwn/2003/09/tax_revolt_in_a.html

Bartle, R. (2004). Designing Virtual Worlds. Indianapolis, Ind.: New Riders Pub.

Boellstorff, T. (2008). Coming of Age in Second Life. New Jersey: Princeton University Press.

Cosgrove, D. (1998). Social Formation and Symbolic Landscape. Madison: University of Wisconsin Press.

Debord, G. (1983). The Society of the Spectacle. Detroit: Black \& Red.

Dibbell, J. (2006). Play Money: Or, How I Quite My Day Job and Made Millions Trading Virtual Loot. New York: Basic Books.

Fornas, J. (2002). Into Digital Borderlands. In J. Fornas (Ed.), Digital borderlands: Cultural Studies of Identity and Interactivity on the Internet. New York: Peter Lang.

Grimmelmann, J. (2003). The State of Play: On the Second Life Tax Revolt. LawMeme (September 21). Retrieved from http://research.yale.edu/lawmeme

Hiltz, R., \& Turoff, M. (1978). The Network Nation: Human Communication via Computer. Reading, MA: Addison-Wesley.

Hudson-Smith, A. (2002). 30 Days in Active Worlds: Community, Design and Terrorism in a Virtual World. In R. Schoeder (Ed.), The Social Life of Avatars, Presence and Interaction in Shared Virtual Environments. London: Springer-Verlag.

McLuhan, M. (1962). The Gutenberg Galaxy; The Making of Typographic Man. Toronto: University of Toronto Press.

Mill, R. (1998). Cyber: Sexual Chat on the Internet. Journal of Popular Culture, 32(3), 31-46. https://doi.org/10.1111/j.0022-3840.1998.3203_31.x

Ondrejka (Linden), Cory, R. (2004). Escaping the Gilded Cage: User Created Content and Building the Metaverse. Retrieved from http://papers.srrn.com/sol3/paper.cfm?abstract_id=538362

Ong, W. (1982). Orality and Literacy: The Technologizing of the Word. London: Methuen.

Pearce, C. (2006). Playing Ethnography: A Study of Emergent Behavior in Online Games and Virtual Worlds. Ph.D. Thesis: SMARTlab Centre, Central Saint Martins College of Art and Design, University of the Arts, London.

Pottage, A. (2001). Persons and Things: An Ethnographic Analogy. Economy and Society, 30(1), 112-138. https://doi.org/10.1080/03085140020019115

Reed, A. (2005). 'My Blog is Me': Texts and Persons in UK Online Journal Culture (and Anthropology). Ethnos, 70(2), 220-242. https://doi.org/10.1080/00141840500141311

Reid, E. (1999). Hierarchy and Power: Social Control in Cyberspace. In M. Smith \& P. Kollock (Eds.), Communities in Cyberspace. London: Routledge.

Rutter, J., \& Gregory, S. (2005). Ethnographic Presence in Nebulous Setting. In C. Hine (Ed.), Virtual Methods: Issue in Social Research on the Internet (pp. 81-92). Oxford: Berg. https://doi.org/10.1080/01972240701884011

Rymaszewski, M. et al. (2007). Second Life. Published by John Wiley \& Sons, Inc., Hoboken, New Jersey.

Sterling, B. (1992). The Hacker Crackdown: Law and Disorder on the Electronic Frontier. New York: Bantam Books.

Taylor, T. (2006). Play Between Worlds: Exploring Online Game Culture. Cambridge, MA: MIT Press.

Veblen, T. (1899). The Theory of the Leisure Class. New York: Dover Publications.

\section{Copyrights}

Copyright for this article is retained by the author(s), with first publication rights granted to the journal.

This is an open-access article distributed under the terms and conditions of the Creative Commons Attribution license (http://creativecommons.org/licenses/by/4.0/). 